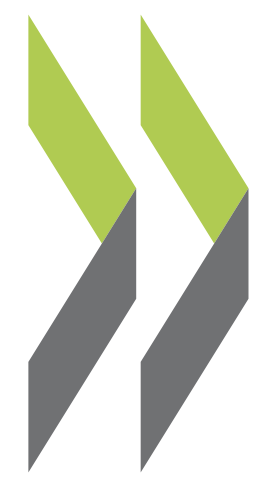

OECD Economics Department Working Papers No. 361

$$
\begin{array}{r}
\text { After } \\
\text { the Telecommunications } \\
\text { Bubble }
\end{array}
$$

Patrick Lenain, Sam Paltridge 
Organisation de Coopération et de Développement Economiques

Organisation for Economic Co-operation and Development

25-Jun-2003

ECONOMICS DEPARTMENT

English text only

AFTER THE TELECOMMUNICATIONS BUBBLE

ECONOMICS DEPARTMENT WORKING PAPERS NO.361

by Patrick Lenain and Sam Paltridge

All Economics Department Working Papers are now available through OECD's Internet Web site at http://www.oecd.org/eco 
ECO/WKP(2003)15

\section{ABSTRACT/RÉSUMÉ}

\section{After the telecommunications bubble}

An unprecedented "boom and bust" investment cycle occurred in the high-tech industries at the turn of the century, in particular in the telecommunications sector. Regulatory reforms and technological innovation fuelled expectations of robust growth in traffic, revenue and earnings. Eventually, however, the volume of traffic expanded less than anticipated. Faced with severe financial difficulties, telecommunication firms sharply curtailed their investment and embarked on restructuring. The impact of such restructuring on the overall economy has been relatively small, but it has had severe upstream effects on equipment suppliers and technology firms. Confidence is now slowly returning to the sector thanks to the efforts of companies to strengthen their balance sheets and to renegotiate their debts. Although the necessary restructuring now underway in the industry is painful, governments and regulators should resist the temptation to provide relief to companies by easing competition requirements or by providing financial help. Indeed, competition is still hampered in some market segments, particularly high-speed internet access, which deprives consumers and businesses of some of the benefits of technological innovation. Changing the rules used for the auction of UMTS spectrum should also be considered with great caution.

JEL codes: L96, D84, L5, D44

Keywords : Telecommunications, bubbles, regulations, auctions

$* * * * * *$

\section{Après la bulle des télécommunications}

Le changement de siècle a été marqué par un cycle sans précédent d'expansion rapide suivie d'un effondrement de l'investissement dans les industries de haute technologie, notamment dans le secteur des télécommunications. Les réformes de la réglementation et l'innovation technologique ont nourri les anticipations de croissance forte du trafic, des recettes et des bénéfices. Mais finalement, le volume du trafic n'a pas progressé autant qu'on l'espérait. Confrontées à de graves difficultés financières, les entreprises de télécommunications ont fortement réduit leur investissement et elles se sont engagées dans une politique de restructuration. Cette restructuration n'a eu sur l'économie générale qu'une incidence relativement limitée, mais ses effets ont été particulièrement marqués en amont, sur les fournisseurs d'équipements et les entreprises de technologie. La confiance revient maintenant lentement dans le secteur, grâce aux efforts des entreprises pour renforcer leurs bilans et renégocier leurs dettes. Même si la restructuration nécessaire actuellement en cours dans l'industrie est douloureuse, les pouvoirs publics et les autorités de réglementation devraient résister à la tentation d'aider les entreprises en assouplissant les contraintes de la concurrence ou en leur accordant un soutien financier. De fait, la concurrence est toujours entravée sur certains segments du marché, notamment l'accès à haut débit à Internet, ce qui prive les consommateurs et les entreprises de certaines retombées de l'innovation technologique. La modification des règles utilisées pour la mise aux enchères des fréquences UMTS devrait également être considérée avec une grande prudence.

Classification JEL : L96, D84, L5, D44

Mots clés : télécommunications, bulles, réglementations, enchères

\section{Copyright: OECD 2003}

Applications for permission to reproduce or translate all, or part of, this material should be made to: Head of Publications Service, OECD, 2 rue André-Pascal, 75775 Paris Cedex 16, France. 
TABLE OF CONTENTS

AFTER THE TELECOMMUNICATIONS BUBBLE.

BIBLIOGRAPHY 19

\section{Boxes}

Box 1. The OECD-wide regulatory reform in telecommunications markets .......................................... 6

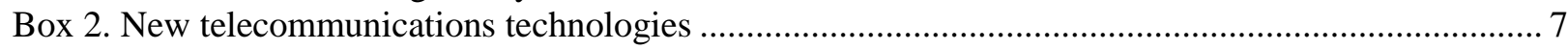

\section{Table}

1. Allocation of $3 \mathrm{G}$ licenses in $\mathrm{OECD}$ countries 17

\section{Figures}

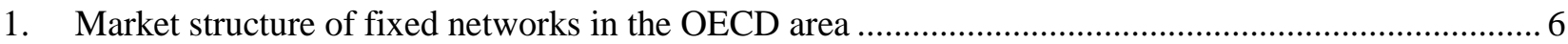

2. Share price indices of selected telecommunications operators.......................................................... 9

3. 12-month rolling average default rates in the telecommunications sector versus all industries ........... 10

4. United States: Capacity utilization rate of the communications equipment suppliers ......................... 11

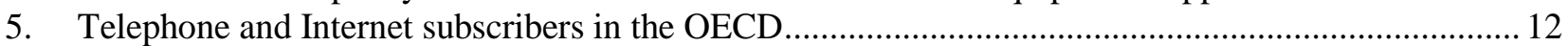

6. Telecom services contribution to core inflation in the euro area ..................................................... 14

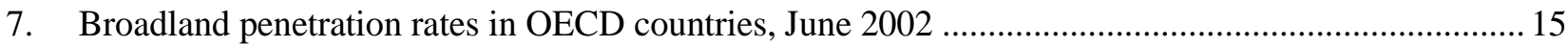


ECO/WKP(2003)15

\title{
AFTER THE TELECOMMUNICATIONS BUBBLE
}

\author{
by Patrick Lenain and Sam Paltridge 1
}

\section{Introduction}

1. The turn of the century saw a "boom and bust" investment cycle in the industries of information and communications technology (ICT) of most OECD countries. The telecommunications sector, in particular, increased its capital spending sharply in the 1990s, after governments opened the market to new entrants. Investment was also spurred by the introduction of marketable new technologies -- notably mobile phones and Internet access services. The new regulatory environment, rapid technological innovation and potential for new service development excited the appetite of the investment community. This led to large flows of equity issuance, debt floatation and bank credit. Awash with cash, companies were able to finance large-scale investment projects, notably the construction of vast fibre-optic cable backbones, and pay high prices for the rights to use third generation wireless spectrum networks. When it became clear that the "hype" for the telecommunications sector had gone too far, expectations returned to more realistic levels, investors became much more prudent and financing evaporated. This left companies with severely impaired balance sheets and large non-profitable fixed assets. While demand for telecommunications services continues to grow strongly, the path to recovery requires a period of retrenchment and restructuring before investors' and creditors' confidence can be restored.

2. In most cases, market forces have been allowed to correct past imbalances, without public interference. It is generally considered that competitive markets are the appropriate environment to encourage adjustment through restructuring. Some participants and observers nonetheless suggest that regulators should provide a degree of relief during this difficult phase, to moderate competition and encourage new investment. It has also been argued that a number of European governments sold spectrum licenses at excessive prices in 2000 and 2001 -- at the peak of the bubble -- and that consequently the "rules of the game" should be relaxed in order to make new mobile telephony investments profitable.

3. After examining the present economic situation of the telecommunications sector, this paper discusses these policy issues. Several findings emerge:

- First, the restructuring of the sector is well underway. Companies have entered into negotiations with creditors to reorganise their liabilities and strengthen their balance sheets. This is facilitated in some countries by legal provisions for debt renegotiations -- such as Chapter 11 of the US Bankruptcy Law -- while elsewhere debt restructuring is more gradual. Thanks to this progress, confidence is slowly coming back.

1. This paper was originally produced as a chapter of the Economic Outlook No. 73. The authors are members of the OECD Secretariat (Economics Department and the Directorate for Science, Technology and Industry). They are grateful to Jean-Philippe Cotis, Jorgen Elmeskov, Mike Feiner and other colleagues for helpful advice and suggestions. The paper draws heavily on OECD Communications Outlook: 2003 Edition. It benefited from the analysis of France's Autorité de Régulation des Télécommunications (ART), even though it does not necessarily reflect the views of this institution. The authors also thank Deborah Bloch for statistical assistance and Nathalie Macle for expert word processing. 
- Second, empirical evidence suggests that the macroeconomic impact of the sector's restructuring is small, reflecting its relatively limited GDP weight, but with significant upstream effects, notably on equipment suppliers. Judged from the robust demand from consumers and businesses, however, the telecommunications services and equipment sectors should return to steady growth once financial restructuring is completed.

- Third, present circumstances do not appear to justify a fundamental shift in regulatory policy. Dynamic competition is still hampered in some market segments, in particular high-speed Internet access, which deprives consumers and businesses from some windfall benefits of ICT innovations. Regulators are adapting their frameworks to changing circumstances, rolling back regulation where competition has emerged, and strengthening it where incumbents still retain dominant positions. They are also taking steps to make regulation more technology-neutral, which would spur inter-modal competition (cable, wireless, fixed lines, satellite) and help resolve some of the present problems with the unbundling of local loops (access of new entrants to subscribers' lines). More generally, financial help from governments does not seem to be a promising way to support the sector's recovery.

- Finally, available evidence does not clearly suggest that the European auctions of Universal Mobile Telecommunications System (UMTS) licenses were inefficient. The main purpose of the auctions, from a regulatory policy perspective, was to allocate licenses in a competitive and transparent manner. This goal was achieved in OECD countries. Nonetheless, a reform of some regulatory aspects of third generation $(3 \mathrm{G})$ licenses might be considered, in particular transferability, as this would facilitate market entry, spur competition and speed up the launching of this new type of network. Changing this important rule after having sold spectrum rights might however be seen as providing a government subsidy, because it would make the rights more valuable without changing their price.

\section{A reversal of fortunes}

4. The regulatory framework of the telecommunications industry changed radically during the past decade in almost all OECD countries, particularly after 1996-97 (Box 1). As technological innovation made competition increasingly possible in the long-distance and international telephony markets, policy makers sought to liberalise the access of new entrants. New independent regulatory agencies were established with a mandate to open markets to competition, prevent incumbents from abusing their position and avoid collusion between operators. Following these decisions, telecommunications markets became more competitive (Figure 1). Other actions were undertaken to liberalise the industry, including number portability and carrier pre-selection. In addition, progress was made towards the privatisation of stateowned operators. 
ECO/WKP(2003)15

Figure 1. Market structure of fixed networks in the OECD area

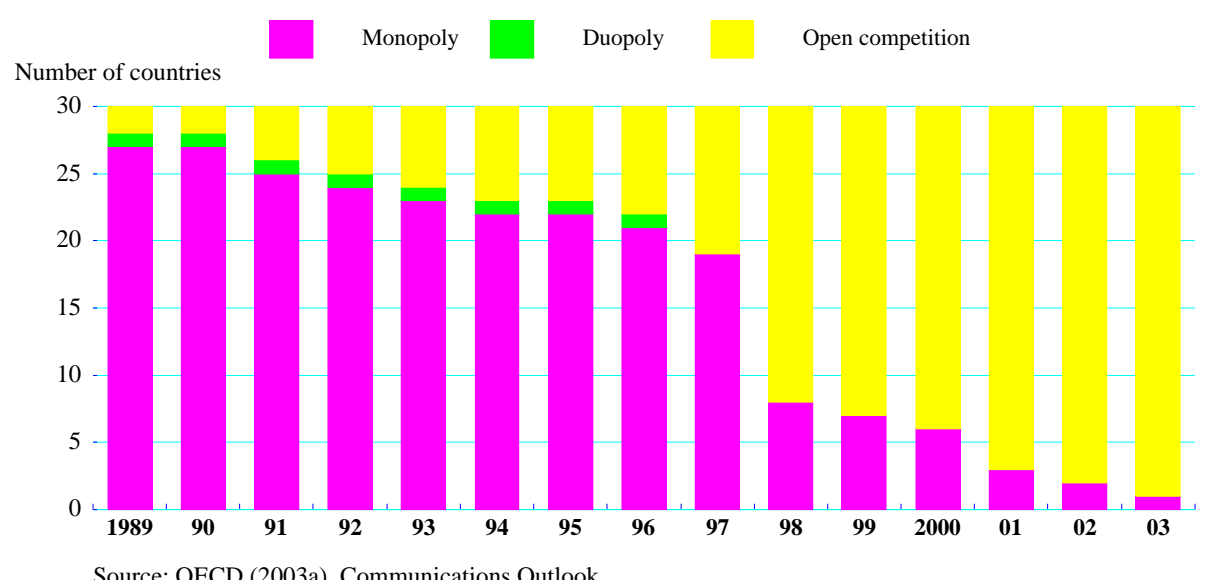

Source: OECD (2003a), Communications Outlook.

\section{Box 1. The OECD-wide regulatory reform in telecommunications markets}

All OECD countries are committed to having competitive markets for telecommunications. ${ }^{1}$ Regulatory frameworks were adapted during the second half of the 1990s to open telecommunications markets to competition and establish an environment conducive to lower prices. New legislation was adopted in the United States under the Telecommunications Act of 1996 and in the European Union under the Telecommunications Directive of 1997. Sector-specific National Regulatory Agencies (NRAs) were set up to complement the roles of economy-wide competition authorities. Fixed line telecommunications markets were opened for a broad range of services -- from international to local calls. Incumbents were required to grant new entrants access to their networks both for voice telephony and high-speed Internet access. Other liberalisation measures included the privatisation or partial privatisation of incumbent public operators; the opening of the sector to foreign ownership; price regulation for services where dominant positions prevail; and other measures such as number portability that enhance consumer choice. As a result of these regulatory measures, competition has intensified and consumers have benefited from greater choice, lower prices and higher quality services. New entrants have gained sizeable shares in the markets for long-distance national and international calls (OECD, 2003a), although the degree of competition prevailing in the United States -- which opened its long distance market in the mid-1980s -- is not yet matched in all OECD countries. In the new markets of mobile telephony and Internet access services, the absence of pre-established market positions has facilitated competition. In mobile telephony, nearly all countries have at least three operators, but the subsidiaries of the incumbent fixed operators often have established predominant market share. ${ }^{2}$ All countries have a plethora of companies providing Internet dial-up (low-speed) access, but much less competition prevails for broadband (highspeed) access as the subsidiaries of fixed line incumbents often tend to dominate this market.

1. Turkey, the last country to open its market, will do so in early-2004 and has already established a regulatory framework for competition.

2. Except in the United Kingdom and the United States where incumbents do not dominate the mobile telephone market. 


\section{Fast market growth was projected...}

5. The liberalisation of the sector, together with the emergence of new telecommunications technologies (Box 2) resulted in high expectations for future revenues and earnings, boosting share prices and allowing unprecedented levels of borrowing. A bright future was predicted for the industry. ${ }^{2}$ For instance, some analysts predicted a doubling of Internet traffic every 90 days and double-digit growth in revenues for services and equipment. ${ }^{3}$ Research analysts at large investment banks encouraged investors to buy shares and bonds issued by telecommunications companies, which they saw as having promising prospects. ${ }^{4}$

\section{Box 2. New telecommunications technologies}

Many technological innovations reached the telecommunications market in the 1990s. New optical technologies made it possible to vastly multiply the transmission capacity of fibre-optic cables. Together with innovation in computers and software this raised the speed at which computers send and receive data and access the Internet. Asymmetric digital subscriber line (ADSL) helped to upgrade traditional copper wires and offer broadband (high-speed) access. Cable television networks were also upgraded to provide Internet access. Cellular mobile operators constructed second generation networks and, in many OECD countries, their customer base grew rapidly, in some cases surpassing the number of fixed network subscribers. The third generation of mobile telephones (Universal mobile telecommunications systems) was promised to become a breakthrough in mobile access to Internet. Technological innovation remains dynamic, which is likely to further change the telecommunications landscape in the future. New wireless technologies -- such as Wireless-Fidelity (Wi-Fi) and other wireless networks -- are likely to influence future trends in the sector.

\section{... but expectations of double-digit revenue growth were over-optimistic...}

6. These high expectations however were not realised. For example, while Internet traffic did grow rapidly (doubling every year), its expansion was significantly slower than earlier predictions. ${ }^{5}$ Also, double-digit increases in telecommunications revenue never materialised. During 1996-2001, telecommunications revenue in the OECD area grew by 7.2 per cent annually on average, but slowed to 1.6 per cent in 2001 under the pressure of the economic downturn. According to preliminary indications for the United States and France ${ }^{6}$, revenues may have been roughly flat in 2002, reflecting a combination of price competition and growing traffic. ${ }^{7}$

2. In May 1997, for instance, William Moroney, President of the Multi Media Telecommunications Association predicted that "the road signs all indicate that, basically, the sky is the limit for communication companies".

3. Telecommucations Industry Association (TIA) (1997).

4. See for instance the testimony of J.B. Grubman before the US House Committee on Financial Services Hearing regarding Worldcom, 8 July 2002.

5. Coffman and Odlyzko (2001).

6. Fixed line telecommunications revenue in the United States is estimated by Merrill Lynch to have declined by 7 per cent in 2002. In contrast, revenue from wireless telephony increased by 17 per cent in 2002 and revenues from data transfer by 33 per cent. In France, overall telecommunications revenue was stagnating by mid-2002, according to the regulatory agency (Autorité de régulation des télécommunications), while traffic increased by 5.6 per cent at constant prices. These numbers should be used with caution, however, 


\section{... and borrowing was excessive}

7. With revenues increasing much less rapidly than expected, the business plans of telecommunications operators became highly vulnerable and market sentiment changed rapidly. Creditors and investors revised their expectations of earnings growth towards more realistic levels when they became aware of the degradation of net margins and the increase in debt stocks. It also became clear that the wave of mergers and acquisitions in the sector, especially in Europe, had taken place at excessively high prices, and that take-over companies might have to significantly write-down the value of acquired assets. Confidence was further undermined in June 2002 when Worldcom, one of the largest US telecommunications long-distance operators, issued a first financial restatement of $\$ 3.8$ billion and subsequently defaulted on its debt payments. This raised the fear that inappropriate accountancy and governance practices had prevailed in the sector. ${ }^{8}$ Stock markets reacted by pushing telecommunications equity prices down, notably in Europe and Japan where they had previously recorded the most spectacular increases (Figure 2). The negative sentiment spilled over to the bond market. Rating firms downgraded many operators or put them under review. Several large firms -- including Worldcom and Global Crossing -- filed for bankruptcy under Chapter 11 in the United States and AT\&T Canada undertook a similar proceeding. ${ }^{9}$ This led to a wave of defaults on telecommunications corporate bonds and contributed to the largest cycle of defaults on bonds since the 1930s. Defaults on corporate bonds worldwide reached $\$ 163$ billion in 2002, of which 56.4 per cent in the telecommunications sector ${ }^{10}$, including some investment grade companies ${ }^{11}$ (Figure 3). The fear of bankruptcy and default resulted into a sharp increase in corporate bond spreads in the middle of 2002. The overall impact on bond markets was, however, limited. Telecom defaults represented 3.2 per cent of the value of bonds outstanding, more than during the previous peak in 1991, but not enough to trigger systemic risk or a credit crunch. ${ }^{12}$

because the definition of telecommunications revenue may vary considerably, as well as their consolidation.

7. The overall growth of communication traffic reflects diverging trends across market segments. Fixed line voice telephony traffic tends to stagnate or decline, whereas wireless and Internet access grow strongly.

8. The role of research analysts at large investment banks was also put into questions, and some banks agreed to pay fines in settlement of cases regarding their dealings.

9. According to Bankruptcy.com, among the largest 15 public companies in the United States that went bankrupt in 2002, eight were communications operators: Worldcom (assets of \$104 billion), Global Crossing ( $\$ 31$ billion), Adelphia Communications ( $\$ 22$ billion), NTL ( $\$ 13$ billion), XO Communications ( $\$ 8$ billion), Williams Communications ( $\$ 6$ billion), McLeod USA ( $\$ 5$ billion) and Asia Global Crossing (\$4 billion).

10. Moody’ Investors Services (2003), Default and Recovery Rates of Corporate Bond Issuers, Global Credit Research, February.

11. Investment grade companies that defaulted in North America included AT\&T Canada, MCI Wordcom, Inc., and its subsidiary SkyTel Communications, Teleglobe and Qwest Communications International.

12. Bernanke (2003). 
8. The combination of financial excesses and corporate governance malpractice has triggered a number of legal challenges. In the United States, ongoing grand jury subpoenas into companies' accounting practices and lawsuits filed by various groups (minority shareholders, bondholders and other creditors) brought uncertainty regarding future financial obligations. The quality of information provided to shareholders at the time of mergers and acquisitions has also been challenged before the courts in some European countries. Operators are still attempting to unravel some complex legal issues linked to their international expansion. ${ }^{13}$

Figure 2. Share price indices of selected telecommunications operators
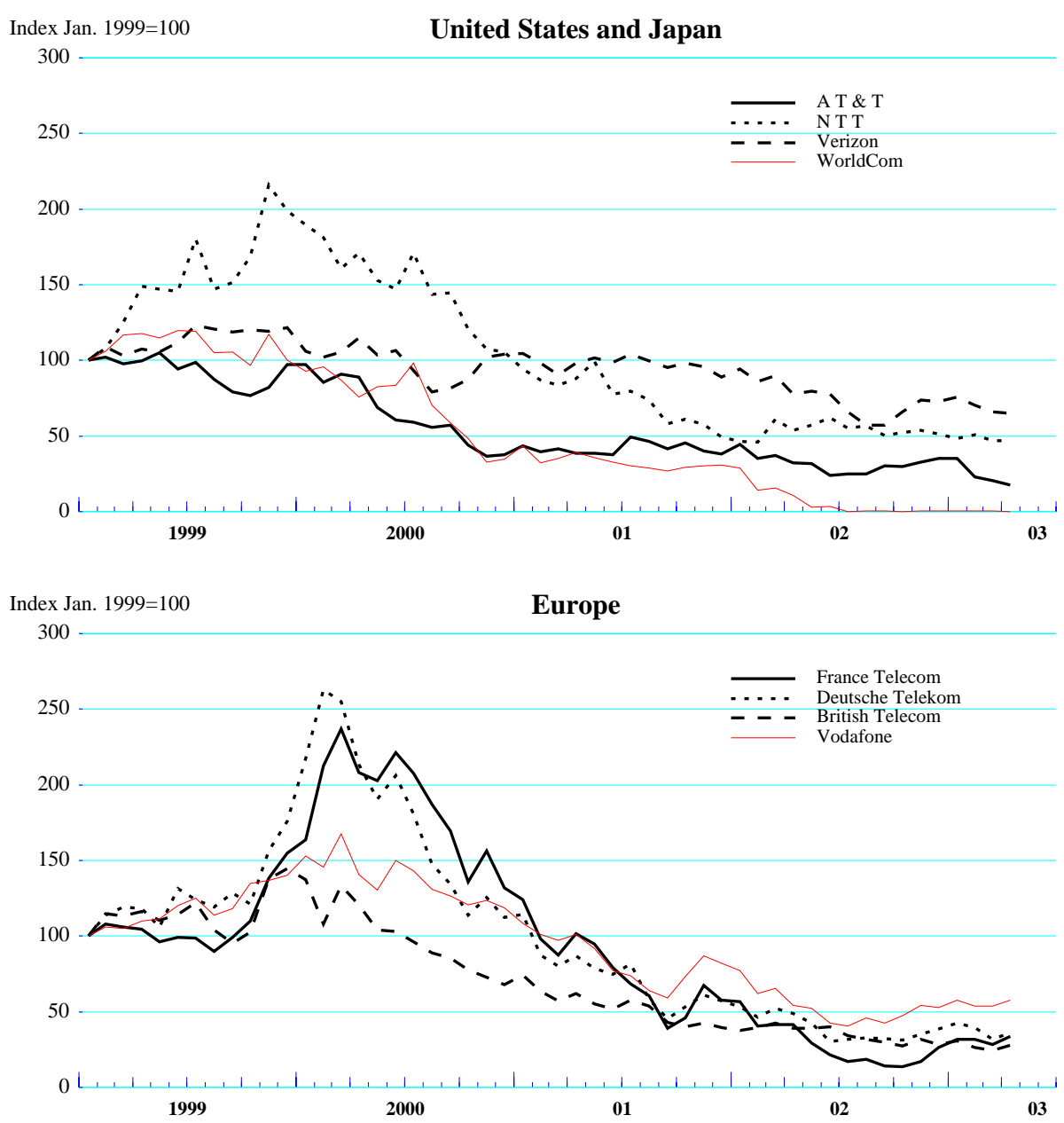

Source: Datastream.

13. For instance, France Telecom has been involved in complex legal issues involving its stake in a German wireless company (Mobilcom). 
Figure 3. 12-month rolling average default rates in the telecommunications sector versus all industries

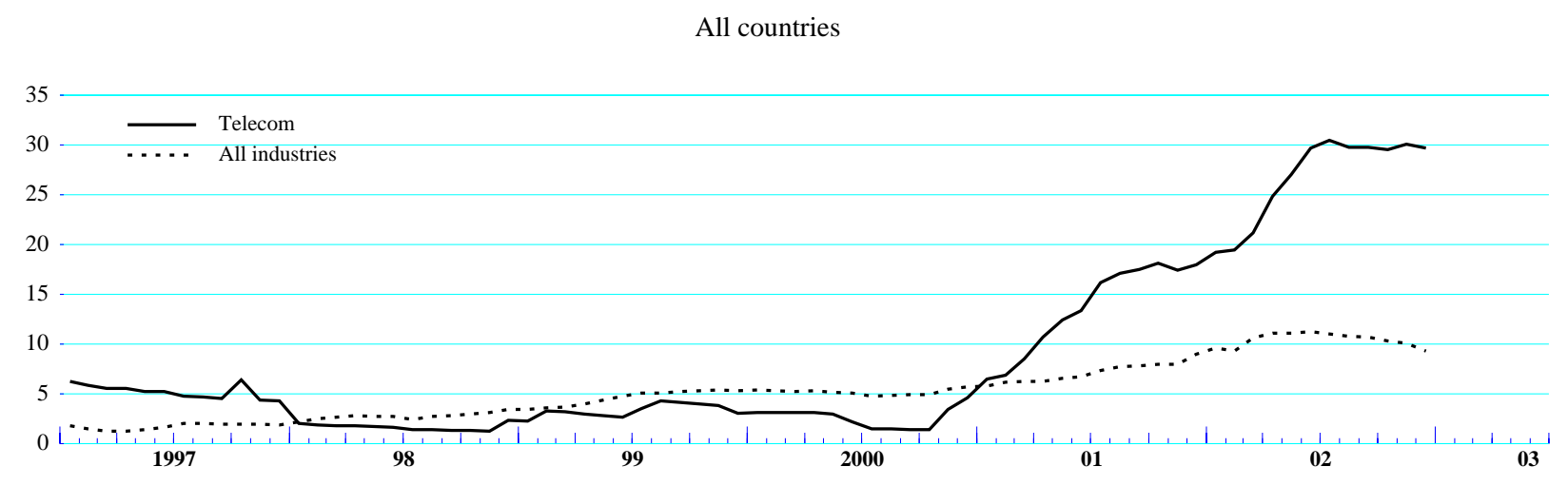

Source: Standard \& Poor's CreditPro® 6.2.

\section{The industry is in the middle of a deep financial restructuring...}

9. Burdened by high debts, many operators have embarked on restructuring programmes to cut costs, reduce debt, sell assets and strengthen balance sheets. In the United States, firms that filed for bankruptcy under Chapter 11 are negotiating with the various groups of claimants to obtain majority approval ${ }^{14}$ for the reorganisation of their liabilities. During the re-negotiation period, firms do not exit the market and continue to provide their services. Management in some companies was able to gain majority approval for the restructuring of their debts. Reorganisation plans have typically cancelled all existing equity shares, which ceased to be valid, and provided for an exchange of bonds against newly floated shares, at a fraction of the face value. Some firms have also bought back or traded their liabilities (or their subsidiaries' debts) at a significant discount from face value, thus reducing their indebtedness. In Canada, similar steps were taken. ${ }^{15}$ In continental Europe, where bankruptcy procedures similar to Chapter 11 do not exist, several incumbents that have accumulated very large debts have embarked on gradual approaches to reduce their obligations. They typically combine sales of non-essential assets, reductions in investment and current spending, debt refinancing and new equity issuance. In countries where companies are still partially state-owned, government funding and loan guarantees are also envisaged. ${ }^{16}$

10. The direct macroeconomic impact of this restructuring is not substantial, reflecting the telecommunications sector's relatively small weight in national economies (between 2 and 4 per cent of GDP), but it has a significant upstream impact on equipment suppliers and technology firms and contributes to reduced high-tech share prices.

14. Under the provisions of the US Bankruptcy Reform Act of 1978 and supplementary legislation in 1994, the management of firms that file for bankruptcy under Chapter 11 has 120 days to prepare a reorganisation plan (this period can be extended by the courts), and a further two months to gain the approval of the creditors. The reorganisation plan must be approved by the majority of creditors (representing two-thirds of claims) in each class of claimants.

15. For instance, AT\&T Canada obtained approval from its bondholders on a plan to restructure the company's balance sheet and equity. Under the plan, bondholders and other affected creditors receive approximately 17.4 per cent on their claims (part in cash, part in shares of the company).

16. France Telecom for instance announced a three-pronged approach to restructure its debt of $€ 68$ billion. The company is seeking to reduce spending by $€ 15$ billion, raise $€ 15$ billion in new equity (including $€ 9$ billion from the government) and refinance $€ 15$ billion in maturities. 


\section{Investment is being sharply cut back...}

11. The telecommunications industry invested heavily until 2000, when spending on infrastructure reached nearly $\$ 230$ billion in the OECD (about 4 per cent of total business fixed investment). Starting in 2001, long-distance carriers severely slashed their capital expenditure, having no inventories to run down and little operating costs to cut in the short-term. In 2001, investment fell to \$194 billion. Anecdotal evidence regarding telephone equipment manufacturers suggests that capital expenditure was cut even more aggressively in 2002. According to some estimates, ${ }^{17}$ capital spending by US telecommunications service providers may have dropped by 47 per cent in 2002, bringing it back to the level recorded in $1997{ }^{18}$ This retrenchment of capital spending is hurting companies upstream, notably equipment suppliers which had to downsize their activities (Figure 4).

Figure 4. United States: Capacity utilisation rate of the communications equipment suppliers ${ }^{1}$

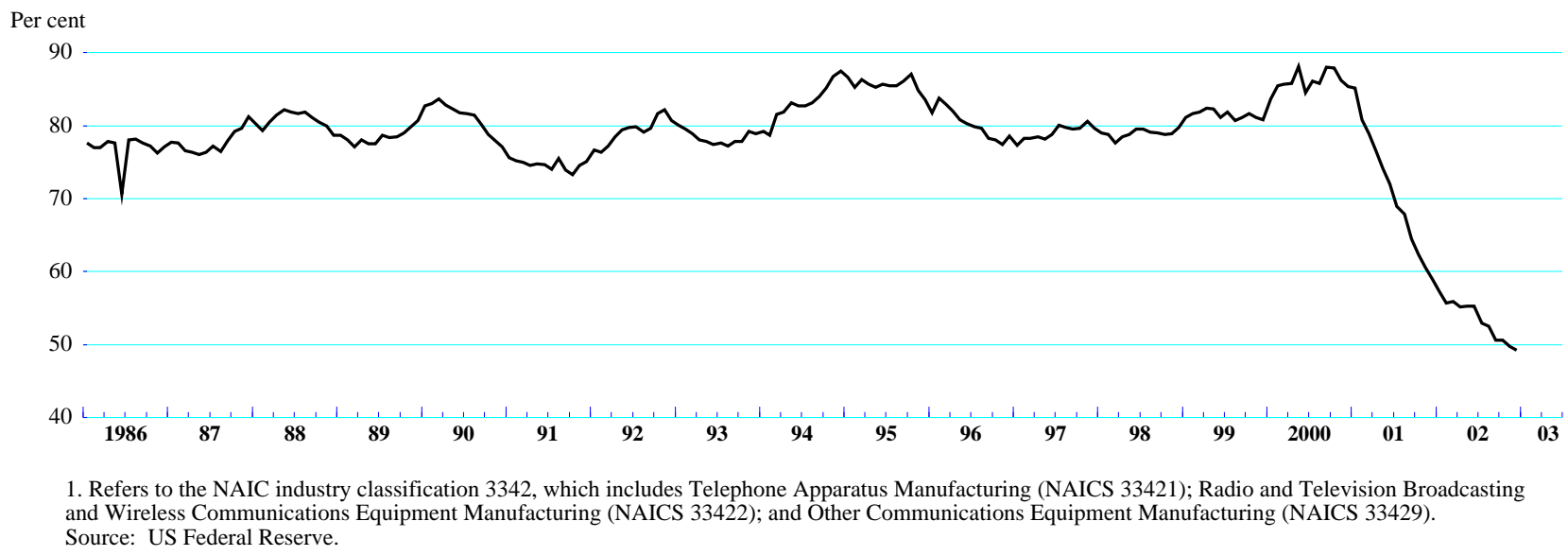

12. For the time being, investment spending cuts appear to be a sensible response to current conditions, and there are no signs that the quality of services has deteriorated. If sustained for a long period, such low level of capital spending may however eventually weaken the capacity of operators to deliver higher-quality services and deploy new technologies. Mobile phone operators must for instance invest to launch their UMTS network, even though they have postponed and downscaled their plans. Internet service providers need to invest to increase their capacity in offering broadband services.

17. TIA (2002).

18. The investment level in 1997 was relatively high historically, but the investment retrenchment is nonetheless severe. 


\section{... but evidence on R\&D spending cuts is inconclusive}

13. The telecommunications industry is likely to have cut back its spending on research and development to improve financial results, although available evidence suggests that this was not the case for all operators. Until 2001, leading telecommunications carriers maintained research and development (R\&D) expenditure in the order of $\$ 6$ to $\$ 7$ billion, in part because some countries' regulation require them to allocate a certain amount of their turnover for this activity. In less regulated environments, however, private firms reduced their spending on research and development back to levels of the mid-1990s. Telephone equipment suppliers, which make the bulk of R\&D spending on telecommunications technologies, appear to have sharply curtailed their R\&D activities in the face of financial challenges. ${ }^{19}$

\section{Confidence seems to be returning slowly}

14. Notwithstanding the financial difficulties, the medium-term prospect for telecommunications services appears promising. Consumer demand for telecommunications services continues to grow, as judged by the increase in the number of subscribers (Figure 5) ${ }^{20}$ OECD-wide data on this point goes only to 2001 but evidence from large markets suggests that the number of subscribers expanded further in 2002 . Forthcoming technologies are likely to stimulate it further. The future of individual market segments is however difficult to predict, not least because of technological and service development. Households may substitute mobile services for some fixed services, thus exacerbating the problems of fixed line operators, although the magnitude of this shift is difficult to predict.

\section{Figure 5. Telephone and Internet subscribers in the OECD}

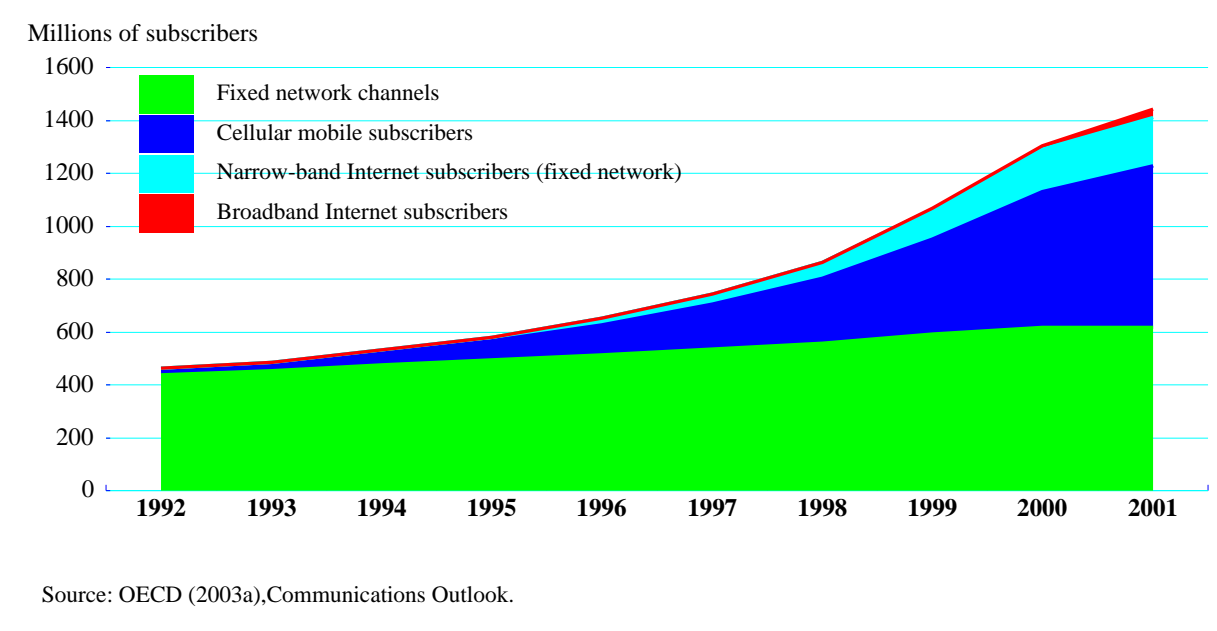

19. According to TIA (2002), the following cuts have been announced: Lucent's Bell Labs reduced R\&D spending by about a third from fiscal year 2001 ( $\$ 3.5$ billion) to fiscal year 2002 ( $\$ 2.3$ billion); CIENA cut R\&D spending by 26 per cent between 31 October 2001 and 31 July 2002; Cisco's R\&D spending was down 10 per cent from 31 October 2001 to 31 July 2002; Nortel Networks reduced R\&D spending by 28 per cent for the period from 30 September 2001 to 30 June 2002; Tellabs cut its R\&D spending by 13 per cent between June 2001 and 31 March 2002; and Ericsson announced plans in 2002 to cut its R\&D costs by $\$ 773$ million and to close half of its $80 \mathrm{R} \& \mathrm{D}$ offices world-wide.

20. Between 1990 and 2000, there was a 65\% increase in monthly household expenditure on communications - the most significant increase of any consumption sector. OECD (2003a) 
ECO/WKP(2003)15

\section{Policy implications}

\section{A debate is underway on the appropriate regulatory policy response to telecommunications' companies financial stress}

15. Despite promising medium-term prospects, the present telecom sector retrenchment is painful, some companies are liquidated, spending is cut and jobs are lost. In these circumstances, some observers have argued that regulators should ease their pro-competition stance to help operators restore healthy balance sheets. Available evidence does not demonstrate, however, that the present financial stress stems from regulatory policy decisions made since the mid-1990s. Incumbents have lost market shares to new entrants following liberalisation but, as noted, the overall market size has grown rapidly and incumbents have generally been able to maintain or even increase revenues. Regulatory policy is of course not a goal in itself and measures constraining firm behaviour should eventually be rolled-back, once a competitive environment has been established. Available evidence suggests however that regulatory interventions are still necessary. In some markets, the ongoing consolidation reduces the number of competitors, which alleviates competitive pressure. In addition, incumbents still dominate certain services.

\section{The consolidation underway may reduce competitive pressure}

16. Like in other sectors that saw many entrants fail, the telecommunications sector is presently consolidating as small firms are going out of business or are being acquired by larger firms. This reduces the number of competitors and may have an upward impact on prices. Available evidence suggests for instance that telecommunications services are contributing much less to disinflation in the euro area, after having been an important moderating factor and despite the ongoing price decline of technology equipment (Figure 6). In the United States, long-distance prices are still on the decline, but there is little sign that the pace of increase in local charges is slowing, despite the opening of this market to competition. In part this is due to tariff rebalancing which operators say more closely aligns prices with costs. It also reflects a trend toward 'bundled' prices for different services being reflected in higher fixed charges. ${ }^{21}$ On the other hand as some market segments consolidate, other highly competitive ones are emerging. One example is the tremendous amount of market entry and experimentation which is occurring by Wireless-ISPs (W-ISPs) using wireless local area networks to provide broadband Internet access.

21. While measuring consumer spending on telecommunications services is straightforward, the average price of such services is more difficult to assess. Fixed network, wireless telephone and Internet access providers offer flat monthly subscription packages, covering different menus of services, which makes it difficult to assess the average price of services really supplied (such as the cost of telephone calls per minute). Hence, some national statistical agencies for the time being exclude mobile phone and Internet services from their consumer price baskets. 
Figure 6. Telecom services contribution to core inflation in the euro area

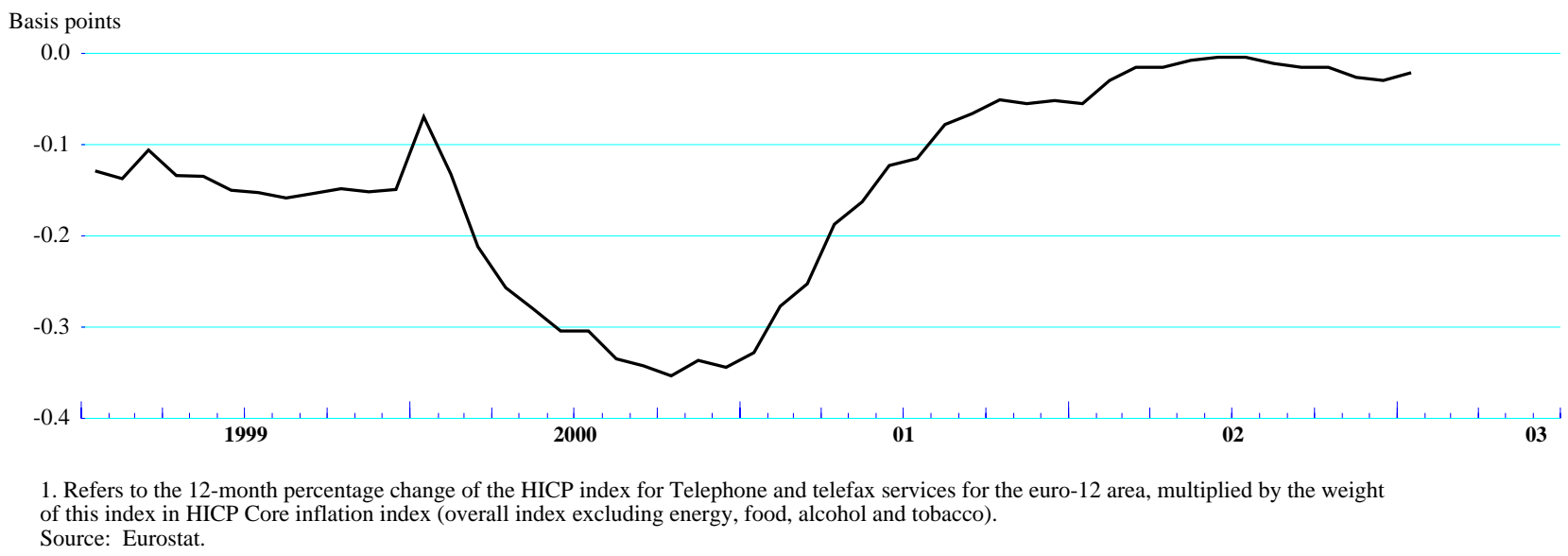

\section{Competition is making slow progress in services requiring access to local loops in the European Union}

17. Available evidence suggests that competition does not yet prevail in a number of market segments. In some cellular wireless communication markets, the small number of operators requires the intervention of regulators to prevent collusion. Prices for terminating calls on mobile networks, from fixed networks, remain relatively high reflecting insufficient competition in that market segment. The unbundling of the local loop is also exemplary of the difficulties encountered by regulators. Indeed, mixed progress has been made across countries in fostering the penetration of Internet broadband access (Figure 7). In the European Union, the opening of local loops was required by a decision of July 2000 and by subsequent national decisions. Implementing legislation is however raising difficult regulatory issues, notably in relation to access prices. Incumbents initially set prices for the use of their infrastructure and lines at levels high enough to discourage access. In addition, they have used delaying tactics related for instance to the need for "collocation" in the operator premises. The pressure of regulators eventually improved conditions for competition, and notably helped reduce the prices charged by incumbent operators. ${ }^{22}$ As a result, the number of subscribers has been growing relatively fast and, by October 2002, about 4 per cent of the European Union's 187 million lines had broadband access. ${ }^{23}$ The bulk of this is, however, provided by incumbent telecommunications companies. New entrants are pursuing aggressive marketing strategies to gain market shares, with limited results so far.

\section{Recent decisions by the US Federal Communication Commission removed some unbundling obligations}

18. In the United States, the 1996 Telecommunications Act required that Incumbent Local Exchange Carriers unbundle their networks and provide access to new entrants, both for voice telephony and broadband Internet access. The Act allowed long-distance companies to enter the market for local calls, hence introducing competition in a segment of the market where "Baby Bell" companies ${ }^{24}$ for the most part

22. In the European Union, the monthly rental of fully unbundled loop averages $€ 12.8$ and the connection charges $€ 103.6$, with considerable variance across countries.

23. European Commission (2002).

24. "Baby Bells" are the local exchange carriers that were created following the break-up of AT\&T. They are specialised in local services (local calls, Internet access). 
had previously held a monopoly. It also made it possible for new entrants to provide high-speed Internet access services via a connection to copper wire networks. In its Triennial Review proceeding concerning incumbent local exchange carriers' network unbundling obligations in February 2003, the Federal Communication Commission (FCC) decided to soften its direct pressure on Baby Bells by delegating unbundling rulings to individual States, which were deemed better placed to assess inter-modal on local competition conditions. States will therefore be responsible for deciding whether local loops should be unbundled and for regulating the prices of such services. At the same time, the FCC lifted Baby Bells' obligations to open their fibre-optic cable network to competitors, which may encourage local companies to invest into such networks, but may also weaken competition in related services in areas without strong inter-model competition. In addition, line-sharing obligations, which are seen as an important form of access for broadband access providers, will be eliminated over a three-year period.

Figure 7. Broadband penetration rates in OECD countries, June 2002

Number of DSL ${ }^{1}$, cable modem lines and other broadband ${ }^{2}$ per 100 inhabitants

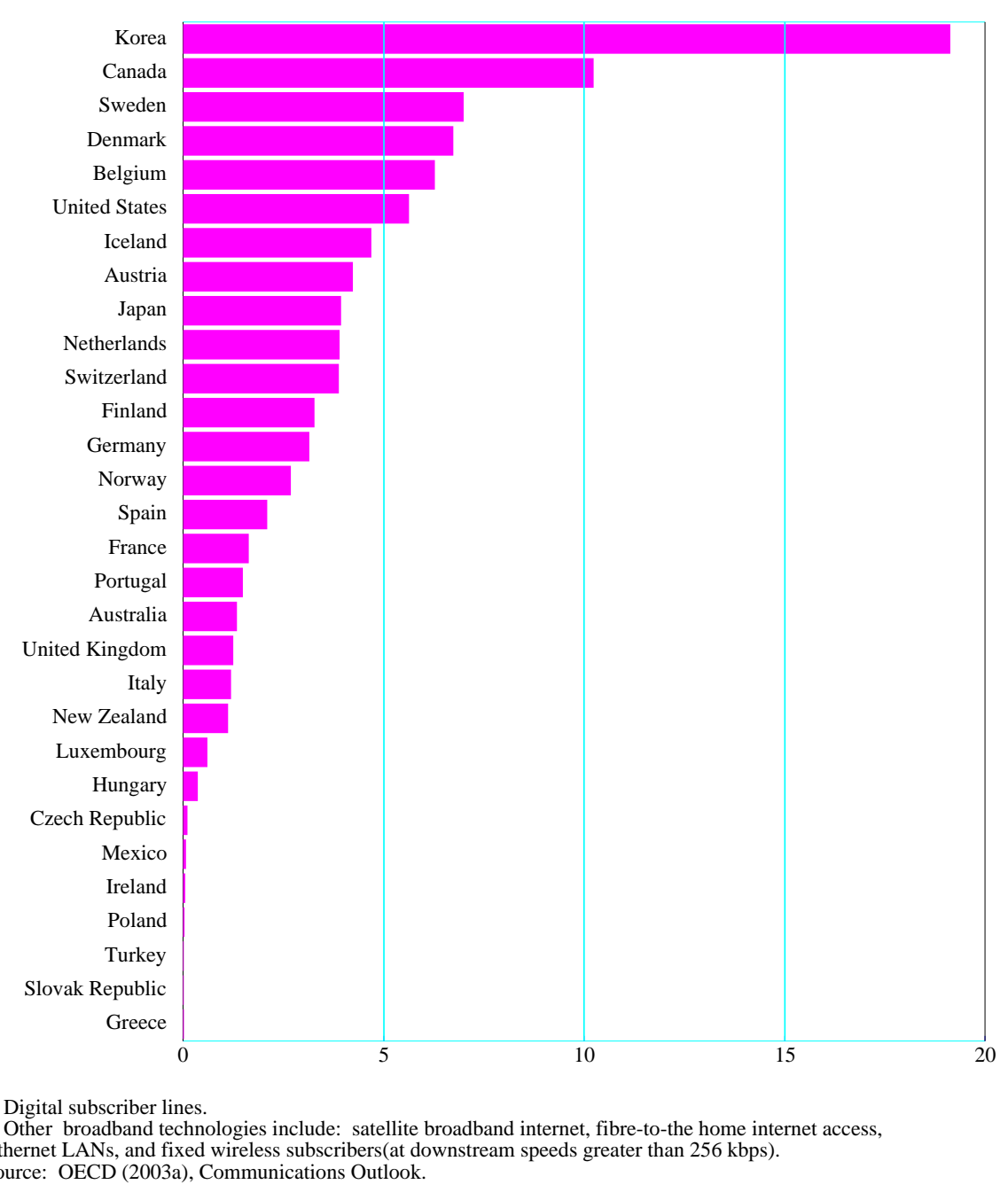




\section{Rapid progress was made recently in Japan}

19. In Japan, regulators required local loop unbundling in March 2000. The incumbents tried however to retain their dominant positions by setting high access prices. Further pressure was exercised by regulators to ease access. ${ }^{25}$ Measures were introduced to set rules for collocation, allow for self-installation of equipment by new entrants and prevent the incumbent companies (Nippon Telegraph and Telephone Corporation, NTT East and NTT West) from accessing privileged information on subscribers. NTT companies were also obliged to provide the necessary information to support competitors in getting access. The overall effect has been to make Japan among the fastest growing markets for high-speed Internet access. New entrants were providing over 60 per cent of the broadband lines in Japan by end-2002.

20. Overall, the example of local loop unbundling shows that the task of opening markets to competition is not yet completed, and that incumbents are still successful in dominating some market segments. While they may eventually relent to regulatory pressure, delaying tactics seem to have been used by incumbents to gain dominant market shares in new markets, which then makes it difficult for new entrants to carve a niche. Hence, there does not seem to be a strong case for providing regulatory relief to distressed incumbents. This would deprive the overall economy from the productivity gains that have been associated with rapid advance in technological innovation. ${ }^{26}$

21. Although a softer policy stance does not appear to be warranted, there is, however, evidence that regulatory policy should become more technology-neutral in several OECD countries. Technological innovation in recent years has made it possible to provide the same services through different technologies. Voice telephony can be provided via fixed lines, mobile phones, and increasingly via cable television networks, satellite and Internet, with power lines perhaps an additional transmission channel in the future. New networks can compete with old networks. In some cases, however, the same company owns both old and new networks, which may impede competition. While progress has been made in some countries to promote inter-modal competition, many restrictions still prevail in others. The decision by the European Union to introduce a new technology-neutral Regulatory Framework in July 2003 is a step in this direction.

\section{Should the allocation of UMTS licenses in Europe be revisited?}

22. In addition to fixed spending on assets, telecommunications operators spent considerable amounts to purchase spectrum licenses, notably in the European Union. The amount committed to buy licenses for UMTS services reached close to $€ 100$ billion (Table 1). Initially heralded as successful market-based sales of public goods, the allocation of licenses in Europe has come under growing scrutiny and debate.

\section{A debate has emerged on the efficiency of $3 G$ licenses in Europe}

23. The European Union required in late 1998 that member states allocate $3 \mathrm{G}$ licenses before end-2001, preferably through auctions. The United Kingdom and Germany, which were among the early movers, were able to raise considerable revenues in 2000. All other member states subsequently sold their licenses at much lower prices because market sentiment towards the telecom sector cooled dramatically,

25. In December 2000, the charge for unbundled line sharing was reduced from $¥ 800$ to $¥ 187$ per month (from about $\$ 6.15$ to only $\$ 1.45$ ).

26. OECD (2003b). 
reducing the amounts that firms and their share-holders were ready to bid. ${ }^{27}$ While there were some differences in their designs, the auctions generally reached the objective of allocating licenses in a competitive and transparent manner. Hence, there is no obvious basis for changing the regulatory stance on the grounds that auction winners paid too much.

Table IV.1. Allocation of 3G licenses in OECD countries

\begin{tabular}{|c|c|c|c|c|}
\hline & $\begin{array}{l}\text { Award } \\
\text { Date }\end{array}$ & $\begin{array}{l}\text { Licensing } \\
\text { Method }\end{array}$ & $\begin{array}{c}\text { Revenue raised } \\
\text { million \$US }\end{array}$ & Remarks \\
\hline Australia & Mar 2001 & Auction & 610 & 48 lots split into 6 licenses \\
\hline Austria & Nov 2000 & Auction & 618 & 6 licenses \\
\hline Belgium & Mar 2001 & Auction & 421 & 3 licenses \\
\hline Canada & Feb 2001 & Auction & 931 & 5 licenses \\
\hline Czech Republic & Dec 2001 & Auction & 200 & 2 licenses \\
\hline Denmark & Sep 2001 & Auction & 472 & 4 licenses \\
\hline Finland & Mar 1999 & Beauty contest & - & licenses awarded to 4 companies, nominal entrance fee \\
\hline France & Jun 2002 & $\begin{array}{l}\text { Beauty contest } \\
\text { with fee }\end{array}$ & 1106 & $\begin{array}{l}2 \text { companies awarded licenses, } 2 \text { licenses still available; entrance fee set at } \\
\$ 4.5 \text { billion each, reduced to } \$ 553 \text { million each plus } 1 \% \text { of revenue }\end{array}$ \\
\hline Germany & Aug 2000 & Auction & 51000 & 6 licenses \\
\hline Greece & Jul 2001 & Hybrid auction & 414 & 3 licenses \\
\hline Ireland & mid-2002 & $\begin{array}{l}\text { Beauty contest } \\
\text { with fee }\end{array}$ & 173 & 4 licenses, but only 3 bidders \\
\hline Italy & Oct 2000 & Hybrid auction & 10070 & 5 licenses \\
\hline Japan & Jun 2000 & Beauty contest & - & 3 licenses, no fees \\
\hline Korea & Aug 2001 & $\begin{array}{l}\text { Beauty contest } \\
\text { with fee }\end{array}$ & 2886 & 3 licenses \\
\hline Netherlands & Jul 2000 & Auction & 2508 & 5 licenses \\
\hline New Zealand & Jan 2001 & Auction & 60 & 4 paying licenses, plus one given for free to cover the Maori people \\
\hline Norway & Nov 2000 & $\begin{array}{l}\text { Beauty contest } \\
\text { with fee }\end{array}$ & 88 & $\begin{array}{l}4 \text { licenses; each winner paying } \$ 11.8 \text { million plus } \$ 2.2 \text { million per year } \\
\text { over the duration of the license ( } 12 \text { years) }\end{array}$ \\
\hline Poland & Dec 2001 & $\begin{array}{l}\text { Beauty contest } \\
\text { with entrance fee }\end{array}$ & 1839 & 3 licenses \\
\hline Portugal & Dec 2000 & $\begin{array}{l}\text { Beauty contest } \\
\text { with fee }\end{array}$ & 360 & 4 licenses \\
\hline Spain & Mar 2000 & $\begin{array}{l}\text { Beauty contest } \\
\text { with fee }\end{array}$ & 480 & 4 licenses \\
\hline Sweden & Dec 2000 & Beauty contest & 44 & 4 licenses, with annual tax of $0.15 \%$ of income each year \\
\hline Switzerland & Dec 2000 & Auction & 120 & 4 licenses \\
\hline United Kingdom & Jun 2000 & Auction & 35400 & 5 licenses \\
\hline United States & $\operatorname{Jan} 2001^{a}$ & Auction & 16857 & $\begin{array}{l}\text { C and F Block Broadband PCS licenses, } 35 \text { winning bidders, other earlier } \\
\text { broadband PCS auctions not included here }\end{array}$ \\
\hline
\end{tabular}

24. Nonetheless, a number of decisions regarding UMTS services regulations are being debated in the current, more difficult environment. Regulatory measures have been suggested to facilitate the financial viability of UMTS networks and accelerate the launching of services. A first proposal is to allow the sharing of infrastructure. Some national regulators are allowing operators to share small parts of their

27. Binmore and Klemperer (2002); Klemperer (2002); and Cable, Henley and Holland (2002). 
networks, mostly for environmental reasons and to reduce negative externalities. ${ }^{28}$ Allowing the sharing of larger parts of infrastructure may however reduce competition and encourage the collusion of operators. Another initiative under consideration would allow operators to transfer their license through secondary market trading. This could be equivalent to a subsidy, however, because it would make a product more valuable after its price has been set. Nonetheless, such a measure would promote competition, because it would put back on the market licenses bought by operators now unable to invest in $3 \mathrm{G}$ infrastructure. As such, it might be a good measure to avoid a reduction in the number of operators and a decline in competition (Didier and Lorenzi, 2002). A third suggestion is to extend the time period during which the radio spectrum rights can be utilised, in view of the delays in launching services.

25. While suggestions for changing the "rules of the game" are plentiful, it may prove difficult to put them into practice. Changing the rules after having allocated the spectrum may encourage auction losers to challenge regulators in courts and create further legal uncertainties.

28. In Germany, for instance, the sharing of sites, masts, antennas, cables and combiners is permitted under certain conditions. 


\section{BIBLIOGRAPHY}

BERNANKE, B.S. (2003), Balance Sheets and the Recovery, Remarks delivered at the 41st Winter Institute, St. Cloud State University, Minnesota, February.

BINMORE, K. and P. KLEMPERER (2002), "The biggest auction ever: the sale of the British 3G Telecom licenses", The Economic Journal, No. 112, March.

CABLE, J., A. HENLEY and K. HOLLAND (2002), "Pot of Gold or Winner's Curse? An Event Study of the Auctions of 3G Mobile Telephone Licenses in the UK", Fiscal Studies, Vol. 23, No. 4.

COFFMAN, K.G. and A.M. ODLYZKO (2001), Growth of the Internet, AT\&T Labs, mimeo.

DIDIER, M. and J.H. LORENZI (2002), Enjeux économiques de l'UMTS, Rapport du Conseil d'analyse économique, La Documentation française, Paris.

EUROPEAN COMMISSION (2002), Eighth implementation report on the telecommunications regulatory package, Brussels, December.

KLEMPERER, P. (2002), "Some observations on the Dutch and German 2G Telecom Auctions", mimeo, September.

OECD (2003a), Communications Outlook 2003, Paris.

OECD (2003b), The Sources of Economic Growth in OECD Countries, Paris.

TIA (Telecommunications Industry Association) (1997), “Telecom Market Projected to Achieve DoubleDigit Growth through year 2000”, Press Release, May 1997, Washington, DC.

TIA (Telecommunications Industry Association) (2002), Investment, capital spending and service quality in US telecommunications networks: a symbiotic relationship, mimeo. 


\section{WORKING PAPERS}

The full series of Economics Department Working Papers can be consulted at www.oecd.org/eco/Working_Papers/

360. Controlling public spending in Iceland

(June 2003) Hannes Suppanz

359. Policies and International Integration: Influences on Trade and Foreign Direct Investment (June 2003) Giuseppe Nicoletti, Steve Golub, Dana Hajkova, Daniel Mirza, Kwang-Yeol Yoo

358. Enhancing the Effectiveness of Public Spending in Finland (June 2003) Philip Hemmings, David Turner and Seija Parviainen

357. Measures of Restrictions on Inward Foreign Direct Investment for OECD Countries (May 2003) Stephen S. Golub

356. Tax Incentives and House Price Volatility in the Euro Area: Theory and Evidence (May 2003) Paul van den Noord

355. Structural Policies and Growth: A Non-technical Overview (May 2003) Alain de Serres

354. Tax Reform in Belgium (May 2003) David Carey

353. Macroeconomic Policy and Economic Performance (April 2003) Pedro de Lima, Alain de Serres and Mike Kennedy

352. Regulation and Investment (March 2003) Alberto Alesina, Silvia Ardagna, Giuseppe Nicoletti and Fabio Schiantarelli

351. Discretionary Fiscal Policy and Elections: The Experience of the Early Years of EMU (March 2003) Marco Buti and Paul van den Noord

350. The US Health System: An Assessment and Prospective Directions for Reform (February 2003) Elizabeth Docteur, Hannes Suppanz and Jaejoon Woo

349. The Effectiveness of Public Expenditure in Portugal (February 2003) Chiara Bronchi

348. Comparative Analysis of Firm Demographics and Survival: Micro-Level Evidence for the OECD Countries (February 2003) Eric Bartelsman, Stefano Scarpetta and Fabiano Schivardi

347. Regulation, Productivity and Growth: OECD Evidence (January 2003) Giuseppe Nicoletti and Stefano Scarpetta

346. Public Expenditure Management in Poland (December 2002) Andrew Burns and Kwang-Yeol Yoo

345. Enchancing the Effectivesness of Public Expenditure in Sweden (December 2002) Deborah Roseveare

344. The Decline in Private Saving Rates in the 1990s in OECD Countries: How Much Can Be Explained by NonWealth Determinants

(November 2002) Alain de Serres and Florian Pelgrin 
343. Enhancing the Effectiveness of Public Expenditure in Norway (October 2002) Isabelle Joumard and Wim Suyker

342. Productivity and Convergence in a Panel of OECD Countries: Do Regulations and Institutions Matter? (September 2002) Stefano Scarpetta and Thierry Tressel

341. Managing Public Expenditure: The UK Approach (August 2002) Paul van den Noord

340. The Brazilian Pension System: Recent Reforms and Challenges Ahead (August 2002) Marcos Bonturi

339. Challenges in the Mexican Financial Sector (August 2002) Marcos Bonturi

338. Coping with Population Ageing in Hungary (August 2002) Andrew Burns and Jaromir Cekota

337. Next Steps for Public Spending in New Zealand: The Pursuit of Effectiveness (July 2002) Dave Rae

336. Strengthening the Management of Public Spending in Hungary (July 2002) Jaromir Cekota, Rauf Gonenc and Kwang-Yeol Yoo

335. Automatic Stabilisers and Market Flexibility in EMU: Is There a Trade-Off? (July 2002) Marco Buti, Carlos Martinez-Mongay, Khalid Sekkat and Paul van den Noord

334. The Economic Consequences of Terrorism (July 2002) Patrick Lenain, Marcos Bonturi and Vincent Koen

333. Investment in human capital through post-compulsory education and training: Selected efficiency and equity aspects (July 2002) Sveinbjörn Blöndal, Simon Field and Nathalie Girouard

332. Enhancing the Effectiveness of Public Spending in Switzerland (June 2002) Isabelle Joumard and Claude Giorno

331. Competition and Efficiency in Publicly Funded Services (June 2002) Jens Lundsgaard

330. Policy Pre-Commitment and Institutional Design: A Synthetic Indicator Applied to Currency Boards (May 2002) Marie-Thérèse Camilleri Gilson

329. The Role of Policy and Institutions for Productivity and Firm Dynamics: Evidence from Micro and Industry Data

(April 2002) Stefano Scarpetta, Philip Hemmings, Thierry Tressel and Jaejoon Woo

328. Improving the Efficiency and Sustainability of Public Expenditure in the Czech Republic (April 2002) Andrew Burns and Kwang-Yeol Yoo

327. Increases in Business Investment Rates in OECD Countries in the 1990s: How much can be explained by fundamentals? (April 2002) Florian Pelgrin, Sebastian Schich and Alain de Serres

326. Sectoral Shifts in Europe and the United States: How They Affect Aggregate Labour Shares and the Properties of Wage Equations

(April 2002) Alain de Serres, Stefano Scarpetta and Christine de la Maisonneuve 